\title{
Characterization and Genetic Potential of Ginger Genotypes Evaluated in Terai Region of West Bengal, India
}

\author{
D. Basak ${ }^{1}$, S. Chakraborty ${ }^{1}$, A. Sarkar ${ }^{1}$, M.K. Debnath ${ }^{2}$, A. Kundu ${ }^{1}$ and S. Khalko ${ }^{3}$ \\ ${ }^{1}$ Department of Genetics and Plant Breeding, ${ }^{2}$ Department of Agricultural Statistics, \\ ${ }^{3}$ Department of Plant Pathology, UBKV, Pundibari, Coochbehar-736165
}

*Corresponding author

\section{A B S T R A C T}

\section{Keywords}

Path analysis, Rhizome thickness, Leven's test, Cluster analysis, Gap statistic, Correlation coefficient

Article Info

Accepted:

10 March 2019

Available Online:

10 April 2019
Character association and path analysis studies were investigated in 2016-2017 and 2017 2018 in all physical and rhizome characters of ginger to find out the influence of characters among themselves on yield. Characters were investigated according to the DUS descriptors as described by Indian Institute of Spices Research, Kozhikode, Kerala. Number of leaves had the highest positive direct effect (1.759) on yield followed by number of shoots (1.053) and rhizome thickness (0.460). The correlation coefficients among the different characters at phenotypic and genotypic levels revealed that Rhizome thickness $\left(0.45^{*}\right)$ was the only trait having positive and significant correlation with rhizome yield $(\mathrm{t} / \mathrm{ha})$. Number of leaves had the highest positive direct effect on yield followed by number of shoots and rhizome thickness indicating that selection should be made on the basis of these characters taking other characters into consideration, while making improvement in yield of ginger. In cluster analysis, gap statistics was done to find optimal number of clusters and two groups of clusters were found. So, genotypes GCP-39, SEHP-9, SE-8640, SG-2640, SE-8681 and ACC-247 should be chosen for cultivation among these genotypes in this region of West Bengal.

\section{Introduction}

Ginger was originated in the tropical rainforest in South-East Asia although ginger no longer grows wild, and it is thought to have originated on the Indian sub-continent because the ginger plants grown in India show the largest amount of genetic variation. Ginger was exported to Europe via India in the first century AD and was used extensively by the Romans. India has been known from prehistoric times as the land of spices. Until the 1970s, India had a virtual dominance in the international spices trade. India still continues to be the largest producer, consumer, and exporter of spices flavour foods in over 130 countries and their intrinsic values make them distinctly superior in terms of taste, colour and fragrance. The USA, Canada, Germany, Japan, Saudi Arabia, Kuwait, Bahrain and Israel are the main markets for Indian spices. The main ginger 
growing countries are India, China, Jamaica, Taiwan, Sierra Leone, Nigeria, Fiji, Mauritius, Indonesia, Bangladesh, Philippines, Sri Lanka, Thailand, Trinidad, Uganda, Hawaii, Guatemala, and many Pacific Ocean Islands(Peter, 2007).

Ginger has many fibrous roots, aerial shoots (pseudo shoots) with leaves and the underground stems (rhizome) (Ravindran and Babu, 2005). The economic part of ginger is rhizome, modified underground stem, often sending out roots and shoots from its nodes. Plant height can reach $90 \mathrm{~cm}$ when it is fully grown (Rashid et al., 2013), the leafy shoot is the pseudo-stem constituted of leaf sheath and bears 8-12 leaves (Vasala, 2001). The leaves are lanceolate to linear-lanceolate with 15-30 $\mathrm{cm}$ in length (Malhotra and Singh, 2003) and 2-3 cm width with sheathing bases (Mishra et al., 2012) which die off each year.

\section{Materials and Methods}

The estimates of variability viz. coefficient of variability (phenotypic and genotypic), heritability (in broad sense), genetic advance and genetic gain (as percent of mean) were worked for selection of various characters. 18 genotypes of ginger were taken for characterization, evaluation in this region in order to find out the suitability of growing in this region. The list of genotypes was given in Table 1.

The list of characterization of different morphological studies including vegetative characters and rhizome characters were given in Table 2 which were done by Indian Institute of Spices Research. Each piece was 2.5 to $5 \mathrm{~cm}$ long and 22 to $25 \mathrm{gm}$. in weight. The genotypes were sown in a randomized complete block design (RCBD) with 3 replications during two consecutive seasons of 2016 - 2017 and 2017- 2018.The phenotypic and genotypic coefficients of variation were calculated by using the formulae given by Burton and De-Vane (1953).The estimates of PCV and GCV were classified as low $(<15 \%)$, moderate $(15-30 \%)$ and high $(>30 \%)$. Heritability in broad sense $\left(\mathrm{h}_{\mathrm{b}}^{2}\right)$ was estimated according to Allard (1960).The estimates were classified as low $(<50 \%)$, moderate $(50-80 \%)$ and high $(>80 \%)$ suggested by Robinson, 1996). The present investigation on genetic divergence was worked out on 18 genotypes based on 8 characters. The more diverse the parents, within overall limits of fitness, the greater the chances of obtaining higher amount of heterotic expression in $\mathrm{F}_{1}$ and broad spectrum of variability in segregating generations. The objective of this work is to group a set of 18 genotypes into different clusters according to the genetic divergence. The statistical analysis was carried out by using statistical software $\mathrm{R}$ 3.5.3 (https://cloud.r-project.org/).

\section{Results and Discussion}

\section{Coefficients of variability}

High GCV value was observed for yield (t/ha) $(43.26 \%)$ and number of shoots $(32.4 \%)$ (Table 3). Moderate GCV value was observed for height of shoot (19.46\%), number of leaves $(15.96 \%)$ and rhizome thickness $(15.05 \%)$. Lowest GCV value was observed for leaf width $(7.45 \%)$ followed by leaf length (11.22\%) and plant height (13.69\%) (Table $3)$. High PCV value was observed yield (t/ha) (45.2\%). Moderate PCV value was recorded for plant height $(15.8 \%)$, height of shoot $(25.66 \%)$, number of leaves $(23.04 \%)$, leaf length $(15.89 \%)$ and rhizome thickness(15.49\%). Lowest PCV value was observed for number of shoots $(13.36 \%)$ and leaf width (13.36\%) (Table 3).

Similar results were reported for high GCV in rhizome yield by Aragaw et al., (2011); Rajyalakshmi and Umajyothi (2014); Yadav 
(1999) and Sasikumar et al., (1992). High GCVfor number of shoots was also reported by Rajyalakshmi and Umajyothi, (2014); Das et al., (2000); Jatoi and Watanabe (2013) and Mohanty et al., (1981). Similar result for moderate GCV value for number of leaves was observed by Sasikumar et al., (1992) and moderate GCV for rhizome thickness observed by Jatoi and Watanabe (2013). High PCV values were reported by Singh et al., (2002); Rajyalakshmi and Umajyothi (2014) and Aragaw et al., (2011) for rhizome yield. Moderate PCV was reported for plant height by Sasikumar et al., (1992); for number of leaves Sasikumar et al., (1992); for leaf length and rhizome thickness by Sasikumar et al., (1992). Low PCV values were reported by Korla and Tiwari (1999) and Tiwari (2003) for number of shoots and leaf width. Higher magnitude of PCV and GCV was observed for yield per plot. GCV and PCV were moderate for shoot length, number of leaves and rhizome thickness. This indicates wide range of variation among these traits. Lowest values of GCV and PCV for leaf length and leaf width suggested rather limited variability and need to generate more variability for wider spectrum of selection.

\section{Heritability}

Heritability was found high for rhizome thickness (94.26\%) and yield (t/ha) (91.36\%) (Table 3). Moderate heritability was estimated for plant height $(75.06 \%)$, number of shoots $(67.97 \%)$ and height of shoot $(57.51 \%)$. Heritability was found low for leaf length $(49.87 \%)$, number of leaves $(47.98 \%)$ and leaf width $(30.67 \%)$ (Table 3). Similar results for moderate to high heritability for rhizome yield, plant height, height of shoot and number of shoots were reported by Aragaw et al., (2011); Rajyalakshmi and Umajyothi (2014); Singh et al., (2002); Parmar (2011); Islam et al., (2008) and Korla and Tiwari (1999).

\section{Genetic advance and genetic gain}

High genetic gain was observed for rhizome yield (t/ha) $(85.07 \%)$ and number of shoots $(55.04 \%)$ (Table 3). Moderate genetic gain was observed for rhizome thickness $(30.8 \%)$ and shoot length $(30.4 \%)$. Low genetic gain was observed for plant height $(24.43 \%)$, number of leaves $(22.77 \%)$ and leaf length $(16.33 \%)$. Genetic gain was very low for leaf width $(8.5 \%)$ (Table 3). Similar results for high genetic advance and genetic gain were observed for rhizome yield by Aragaw et al., (2011); Rajyalakshmi and Umajyothi (2014); Singh et al., (2002); Parmar (2011); Islam et al., (2008). High heritability coupled with high genetic gain was estimated for yield per plot/ hectare, indicating that it is under additive gene effects and selection would be very effective. High heritability coupled with moderate genetic gain for rhizome thickness, plant height and number of shoots was also observed suggesting that selection would be more effective for these traits.

\section{Correlation studies}

Correlation coefficients among the different characters were worked out at phenotypic and genotypic levels from the pooled data.

\section{Phenotypic correlation}

The phenotypic correlation coefficients among different characters revealed that only rhizome thickness $\left(0.46^{* *}\right)$ had significant positive association with yield ( $\mathrm{t} / \mathrm{ha}$ ) (Table 4). While significant and negative correlation of yield ( $\mathrm{t} / \mathrm{ha})$ with number of shoot $\left(-0.50^{*}\right)$ was observed. Plant height showed significant and positive correlation with shoot height $\left(0.96^{* *}\right)$, number of leaves $\left(0.82^{* *}\right)$, leaf length $\left(0.66^{* *}\right)$, and number of shoots $\left(0.80^{* *}\right)$ (Table 4$)$. Height of shoot showed significant and positive correlation with plant height $\left(0.96^{* *}\right)$, number of leaves $\left(0.90^{* *}\right)$, 
leaf length $\left(0.70^{* *}\right)$, and number of shoots $(0.77 * *)$.Number of leaves showed significant and positive correlation with plant height $\left(0.82^{* *}\right)$, height of shoot $\left(0.90^{* *}\right)$, leaf length $\left(0.71^{* *}\right)$, and number of shoots $\left(0.67^{* *}\right)$.Leaf length showed significant and positive correlation with plant height $\left(0.66^{* *}\right)$, height of shoot $(0.70 * *)$, number of leaves $(0.71 * *)$, number of shoots $(0.81 * *)$ and leaf width $\left(0.63^{* *}\right)$. Number of shoots showed significant and positive correlation with plant height $\left(0.80^{* *}\right)$, height of shoot $\left(0.77^{* *}\right)$, number of leaves $(0.67 * *)$, leaf length $(0.81 * *)$ and leaf width $\left(0.65^{* *}\right)$. Leaf width showed significant and positive correlation with leaf length $(0.63 * *)$ and number of shoots $\left(0.65^{* *}\right)$ (Table 4$)$. Similar result for rhizome thickness was reported by Abraham and Latha (2003), Nandkangre et al., (2016) and Jatoi and Watanabe (2013).

\section{Genotypic correlation}

The genotypic correlation coefficients among different characters revealed that only rhizome thickness $\left(0.48^{* *}\right)$ had significant positive association with yield ( $\mathrm{t} / \mathrm{ha}$ ). All other characters had significant negative association with yield. Yield (t/ha) was found significant and negative correlation with plant height ($0.30 *)$, height of shoot $(-0.47 * *)$, number of leaves $\left(-0.46^{* *}\right)$, leaf length $\left(-0.46^{* *}\right)$, number of shoots $(-0.54 * *)$ and leaf width ($0.26 *$ ) (Table 4). Rhizome thickness showed significant and negative correlation with shoot length $(-0.38 * *)$, number of leaves $(-0.39 * *)$, leaf length $\left(-0.47^{* *}\right)$, number of shoots ($\left.0.35^{* *}\right)$ and leaf width $(-0.61 * *)$. Plant height had significant and positive correlation with shoot length $(0.99 * *)$, number of leaves $\left(0.98^{* *}\right)$, leaf length $\left(0.76^{* *}\right)$, number of shoots $(0.87 * *)$ and leaf width $(0.49 * *)$ (Table 4). Leaf length showed significant and positive correlation with number of shoots $\left(0.90^{* *}\right)$ and leaf width (0.80). Number of leaves showed significant and positive correlation with shoot length $\left(0.96^{* *}\right)$ (Table 4).

The correlation coefficients among the different characters were worked out at phenotypic and genotypic levels. In general, the genotypic correlation coefficients were higher in magnitude than phenotypic correlation coefficients which was also reported by Medhi et al., (2007), indicating a strong inherent association among the traits. The phenotypic and genotypic correlation coefficients among different characters showed that rhizome yield had significantly positive association with rhizome thickness while significantly negative correlation was observed with number of shoots. Rhizome thickness is the only character we may choose for prediction of high yield. Similar result for rhizome thickness was reported by Abraham and Latha (2003), Nandkangre et al., (2016) and Jatoi and Watanabe (2013). Govind and Chandra (1999); Rajyalakshmi and Umajyothi (2014) and Lincy et al., (2008) earlier reported significant negative correlation between number shoots and rhizome yield.

\section{Path coefficient analysis}

Path coefficient analysis from the pooled data of two years depicts the effects of different independent characters individually and in combination with other characters on the dependent character rhizome yield. Considering rhizome yield as effect and seven characters as causes, genotypic correlation coefficients were partitioned by using the method of path analysis, to find out the direct and indirect effects of yield contributing characters towards rhizome yield (Table 5).

\section{Genotypic path}

The data regarding genotypic path revealed that Number of leaves had the highest positive direct effect (1.759) on yield followed by 
number of shoots (1.053) and rhizome thickness (0.460) (Table 5). Number of shoots showed high positive direct effect (1.053) on yield and high positive indirect effect through number of leaves (1.214) (Table 5). Plant height had the highest negative direct effect (1.243) and very high positive indirect effect through number of leaves (1.724) and number of shoots (0.916) (Table 5). Shoot length had high negative direct effect (-1.10) and very high positive indirect effect through number of leaves (1.689) and number of shoots (0.864) (Table 5). Number of shoots showed high positive indirect effect through number of leaves (1.214). Leaf length showed high positive indirect effect through number of leaves (1.214) and number of shoots (0.948) (Table 5). Leaf width also showed high positive indirect effect through number of leaves (1.038) and number of shoots (0.864) (Table 5). The residual effect for genotypic path was 0.993 (Table 5). Number of leaves had the highest positive direct effect on yield followed by number of shoots and rhizome thickness indicating that selection should be made on the basis of these characters taking other characters into consideration, while making improvement in yield of ginger. High positive direct effect of number of leaves, number of shoots and rhizome thickness on rhizome yield was earlier reported by Ravi et al.,(2017); Jatoi et al., (2013); Islam et al., (2008) and Abrahm and Latha (2003).

\section{Distribution of different ginger genotypes into various clusters}

\section{Cluster analysis}

A hierarchical clustering analysis was carried out on different phenotypic traits viz. Plant height $(\mathrm{cm})$, Shoot length $(\mathrm{cm})$, Number of leaves, Leaf length $(\mathrm{cm})$, Number of shoots, Leaf width $(\mathrm{cm})$, Rhizome thickness $(\mathrm{cm})$ and Yield (t/ha) resulted in two clusters (Fig. 1a and Table 6).

Table.1 List of ginger genotypes and their origin

\begin{tabular}{|c|c|c|c|c|c|}
\hline $\begin{array}{l}\text { SI. } \\
\text { No. }\end{array}$ & Name of Genotype & Place of origin & $\begin{array}{l}\text { Sl. } \\
\text { No. }\end{array}$ & $\begin{array}{l}\text { Name of } \\
\text { Genotype }\end{array}$ & Place of origin \\
\hline 1 & GCP-51 & $\begin{array}{l}\text { Dinhata, Cooch Behar,West } \\
\text { Bengal }\end{array}$ & 10 & ACC-578 & IISR, Kerala \\
\hline 2 & GCP-56 & $\begin{array}{c}\text { Totopara, Alipurduar, West } \\
\text { Bengal }\end{array}$ & 11 & SE-8631 & Telengana \\
\hline 3 & $\begin{array}{l}\text { GCP-5 (Garubathan) } \\
\text { Local check }\end{array}$ & $\begin{array}{c}\text { Garubathan, Darjeeling, West } \\
\text { Bengal }\end{array}$ & 12 & ACC-219 & IISR, Kerala \\
\hline 4 & GCP-46 & $\begin{array}{c}\text { Mangalabari, Jaigaon, West } \\
\text { Bengal }\end{array}$ & 13 & SE-8640 & $\begin{array}{l}\text { TNAU, Tamil } \\
\text { Nadu }\end{array}$ \\
\hline 5 & GCP-30 & $\begin{array}{l}\text { Majhian, South Dinajpur, West } \\
\text { Bengal }\end{array}$ & 14 & SG-26-40 & Kerala \\
\hline 6 & GCP-36 & $\begin{array}{l}\text { Uttar Madarihat, Alipurduar, } \\
\text { West Bengal }\end{array}$ & 15 & SE-8681 & Telengana \\
\hline 7 & GCP-39 & $\begin{array}{c}\text { Totopara, Alipurduar, West } \\
\text { Bengal }\end{array}$ & 16 & ACC-247 & IISR, Kerala \\
\hline 8 & GCP-14 & $\begin{array}{l}\text { Jambari, Cooch Behar, West } \\
\text { Bengal }\end{array}$ & 17 & $\begin{array}{c}\text { VARADA } \\
\text { National check }\end{array}$ & $\begin{array}{l}\text { IISR Variety, } \\
\text { Kerala }\end{array}$ \\
\hline 9 & SEHP-9 & Telengana & 18 & KARTHIKA & $\begin{array}{l}\text { Kerela Agricultura } \\
\text { University }\end{array}$ \\
\hline
\end{tabular}


Table.2 Different morphological and rhizome characteristics according to PPV \& FRA act

\begin{tabular}{|c|c|c|c|c|}
\hline S No. & Characteristics & States & Stage of observation & $\begin{array}{l}\text { Type of } \\
\text { Assessment }\end{array}$ \\
\hline 1 & Plant: Height (cm) & $\begin{array}{l}\text { Short }(<100), \quad \text { Medium } \\
(100-120), \text { Tall }(>120)\end{array}$ & $\begin{array}{l}\text { At the end of the } \\
\text { growing phase }\end{array}$ & MS \\
\hline 2 & $\begin{array}{l}\text { Plant: Number of } \\
\text { shoots }\end{array}$ & $\begin{array}{l}\text { Few }(<10) \text {, Medium }(10- \\
\text { 15) Many }(>15)\end{array}$ & $\begin{array}{l}\text { At the end of the } \\
\text { growing phase }\end{array}$ & MS \\
\hline 3 & $\begin{array}{l}\text { Plant: Height of } \\
\text { shoot }(\mathrm{cm})\end{array}$ & $\begin{array}{l}\text { Short }(<75) \text {, Medium }(75- \\
90) \text { Tall }(>90)\end{array}$ & $\begin{array}{l}\text { At the end of the } \\
\text { growing phase }\end{array}$ & MS \\
\hline 4 & $\begin{array}{l}\text { Shoot: Number of } \\
\text { leaves on main } \\
\text { shoot }\end{array}$ & $\begin{array}{l}\text { Few }(<25) \text { Medium }(25- \\
\text { 35) Many }(>35)\end{array}$ & $\begin{array}{l}\text { Full expansion of } \\
\text { leaves achieved }\end{array}$ & MS \\
\hline 5 & Leaf: Length $(\mathrm{cm})$ & $\begin{array}{l}\text { Short }(<25), \text { Medium }(25- \\
\text { 30), Long }(>30)\end{array}$ & $\begin{array}{l}\text { Full expansion of } \\
\text { leaves achieved }\end{array}$ & MS \\
\hline 6 & Leaf: Width $(\mathrm{cm})$ & $\begin{array}{l}\text { Narrow }(<2.5), \text { Medium } \\
(2.5-3.5) \text {, Broad }(>3.5)\end{array}$ & $\begin{array}{l}\text { Full expansion of } \\
\text { leaves achieved }\end{array}$ & MS \\
\hline 7 & $\begin{array}{l}\text { Rhizome: Thickness } \\
\text { (cm) }\end{array}$ & $\begin{array}{l}\text { Thin }(<2) \text {, Medium }(2-3) \text {, } \\
\text { Bold }(>3)\end{array}$ & At the time of harvest & MS \\
\hline 8 & Rhizome: Shape & $\begin{array}{ll}\text { Straight, } & \text { Curved, } \\
\text { Zigzagged } & \end{array}$ & At the time of harvest & VG \\
\hline
\end{tabular}

Table.3 Phenotypic and genotypic coefficient of variation, heritability, genetic advance and genetic gain for nine characters in ginger. (Pooled Data Analysis)

\begin{tabular}{|c|c|c|c|c|c|c|c|c|}
\hline \multirow[t]{2}{*}{ Characters } & \multirow{2}{*}{$\begin{array}{l}\text { Grand } \\
\text { Mean }\end{array}$} & \multicolumn{2}{|c|}{ Range } & \multirow{2}{*}{$\begin{array}{c}\text { GCV } \\
(\%)\end{array}$} & \multirow{2}{*}{$\begin{array}{l}\text { PCV } \\
(\%)\end{array}$} & \multirow{2}{*}{$\begin{array}{l}\text { Heritability } \\
(\%)\end{array}$} & \multirow{2}{*}{$\begin{array}{c}\text { Genetic } \\
\text { advance } \\
(\%)\end{array}$} & \multirow{2}{*}{$\begin{array}{c}\text { Genetic } \\
\text { gain } \\
(\%)\end{array}$} \\
\hline & & Max & Min & & & & & \\
\hline $\begin{array}{l}\text { Plant height } \\
\text { (cm) }\end{array}$ & 59.59 & 70.63 & 50.72 & 13.69 & 15.8 & 75.06 & 14.56 & 24.43 \\
\hline $\begin{array}{l}\text { Height of shoot } \\
\text { (cm) }\end{array}$ & 42.46 & 53.72 & 33.18 & 19.46 & 25.66 & 57.51 & 12.91 & 30.4 \\
\hline $\begin{array}{c}\text { Number of } \\
\text { leaves }\end{array}$ & 14.31 & 16.67 & 10.67 & 15.96 & 23.04 & 47.98 & 3.26 & 22.77 \\
\hline $\begin{array}{l}\text { Leaf length } \\
\text { (cm) }\end{array}$ & 21.25 & 23.79 & 17.64 & 11.22 & 15.89 & 49.87 & 3.45 & 16.33 \\
\hline $\begin{array}{c}\text { Number of } \\
\text { shoots }\end{array}$ & 6.1 & 8.33 & 3.33 & 32.4 & 13.36 & 67.97 & 3.35 & 55.04 \\
\hline $\begin{array}{l}\text { Leaf width } \\
\text { (cm) }\end{array}$ & 2.21 & 2.61 & 1.99 & 7.45 & 13.45 & 30.67 & 0.19 & 8.5 \\
\hline $\begin{array}{c}\text { Rhizome } \\
\text { thickness (cm) }\end{array}$ & 2.24 & 2.95 & 1.88 & 15.05 & 15.49 & 94.26 & 0.67 & 30.08 \\
\hline Yield(tonne/ha) & 5.37 & 8.89 & 3.13 & 43.26 & 45.2 & 91.36 & 4.57 & 85.07 \\
\hline
\end{tabular}


Table.4 Genotypic and phenotypic correlation

\begin{tabular}{|c|c|c|c|c|c|c|c|c|}
\hline & & $\begin{array}{l}\text { Shootlength } \\
\text { (cm) }\end{array}$ & $\begin{array}{l}\text { Number } \\
\text { of leaves }\end{array}$ & $\begin{array}{l}\text { Leaf } \\
\text { length } \\
(\mathrm{cm})\end{array}$ & $\begin{array}{l}\text { Number } \\
\text { of shoots }\end{array}$ & $\begin{array}{l}\text { Leaf } \\
\text { width } \\
(\mathrm{cm})\end{array}$ & $\begin{array}{l}\text { Rhizome } \\
\text { thickness } \\
(\mathrm{cm})\end{array}$ & $\begin{array}{l}\text { Yield } \\
\text { (t/ha). }\end{array}$ \\
\hline \multirow{2}{*}{$\begin{array}{l}\text { Plant height } \\
\text { (cm) }\end{array}$} & $\mathbf{P}$ & $0.96 * *$ & $0.82 * *$ & $0.66^{* *}$ & $0.80 * *$ & 0.39 & -0.17 & -0.28 \\
\hline & G & $0.99 * *$ & $0.98 * *$ & $0.76^{* *}$ & $0.87 * *$ & $0.49 * *$ & -0.19 & $-0.30 *$ \\
\hline \multirow{2}{*}{$\begin{array}{l}\text { Shoot length } \\
(\mathrm{cm})\end{array}$} & $\mathbf{P}$ & & $0.90 * *$ & $0.70 * *$ & $0.77 * *$ & 0.4 & -0.34 & -0.42 \\
\hline & G & & $0.96 * *$ & $0.70 * *$ & $0.82 * *$ & $0.52 * *$ & $-0.38^{*}$ & $-0.47 * *$ \\
\hline \multirow{2}{*}{$\begin{array}{l}\text { Number of } \\
\text { leaves }\end{array}$} & $\mathbf{P}$ & & & $0.71 * *$ & $0.67 * *$ & 0.45 & -0.32 & -0.39 \\
\hline & G & & & $0.69 * *$ & $0.69 * *$ & $0.59 * *$ & $-0.39 *$ & $-0.46^{*}$ \\
\hline \multirow{2}{*}{$\begin{array}{l}\text { Leaf length } \\
(\mathrm{cm})\end{array}$} & $\mathbf{P}$ & & & & $0.81 * *$ & $0.63 * *$ & -0.41 & -0.39 \\
\hline & G & & & & $0.90 * *$ & $0.80 * *$ & $-0.47 * *$ & $-0.46^{* *}$ \\
\hline \multirow{2}{*}{$\begin{array}{l}\text { Number of } \\
\text { shoots }\end{array}$} & $\mathbf{P}$ & & & & & $0.65^{* *}$ & -0.31 & $-0.50 * *$ \\
\hline & G & & & & & $0.82 * *$ & $-0.35^{*}$ & $-0.54 * *$ \\
\hline \multirow{2}{*}{$\begin{array}{l}\text { Leaf width } \\
\text { (cm) }\end{array}$} & $\mathbf{P}$ & & & & & & $-0.53 * *$ & -0.23 \\
\hline & G & & & & & & $-0.61 * *$ & $-0.26^{*}$ \\
\hline \multirow{2}{*}{$\begin{array}{c}\text { Rhizome } \\
\text { thickness } \\
\text { (cm) }\end{array}$} & $\mathbf{P}$ & & & & & & & $0.46^{* *}$ \\
\hline & G & & & & & & & $0.48 * *$ \\
\hline
\end{tabular}

Table.5 Direct (Diagonal) and indirect effect of genotypic path coefficients (Pooled)

\begin{tabular}{|c|c|c|c|c|c|c|c|c|}
\hline & $\begin{array}{l}\text { Plant } \\
\text { height } \\
(\mathrm{cm})\end{array}$ & $\begin{array}{l}\text { Shoot } \\
\text { length } \\
(\mathrm{cm})\end{array}$ & $\begin{array}{c}\text { Number } \\
\text { of } \\
\text { leaves }\end{array}$ & $\begin{array}{l}\text { Leaf } \\
\text { length } \\
(\mathrm{cm})\end{array}$ & $\begin{array}{c}\text { Number } \\
\text { of } \\
\text { shoots }\end{array}$ & $\begin{array}{l}\text { Leaf } \\
\text { width } \\
(\mathrm{cm})\end{array}$ & $\begin{array}{l}\text { Rhizome } \\
\text { thickness } \\
\text { (cm) }\end{array}$ & $\begin{array}{l}\text { Yield } \\
(\mathrm{t} / \mathrm{ha}) \text {. }\end{array}$ \\
\hline Plant height (cm) & -1.243 & -1.133 & 1.724 & -0.276 & 0.916 & -0.2 & -0.087 & $-0.300^{*}$ \\
\hline Shoot length $(\mathrm{cm})$ & -1.28 & -1.1 & 1.689 & -0.255 & 0.864 & -0.213 & -0.175 & $\begin{array}{c}- \\
0.470 * *\end{array}$ \\
\hline Number of leaves & -1.218 & -1.056 & 1.759 & -0.251 & 0.727 & -0.241 & -0.179 & $-0.460 *$ \\
\hline Leaf length $(\mathrm{cm})$ & -0.945 & -0.77 & 1.214 & -0.364 & 0.948 & -0.327 & -0.216 & $\begin{array}{c}- \\
0.460 * *\end{array}$ \\
\hline Number of shoots & -1.081 & -0.902 & 1.214 & -0.327 & 1.053 & -0.335 & -0.161 & $\begin{array}{c}- \\
0.540 * *\end{array}$ \\
\hline Leaf width (cm) & -0.609 & -0.572 & 1.038 & -0.291 & 0.864 & -0.409 & -0.281 & $-0.260 *$ \\
\hline $\begin{array}{c}\text { Rhizome } \\
\text { thickness (cm) }\end{array}$ & 0.236 & 0.418 & -0.686 & 0.171 & -0.369 & 0.249 & 0.46 & $0.480 * *$ \\
\hline \multicolumn{9}{|c|}{ Residual effect $=0.99352$} \\
\hline
\end{tabular}


Table.6 Mean, Range and Variance for various traits of ginger under different clusters evaluated inTerai region of West Bengal

\begin{tabular}{|c|c|c|c|c|c|c|c|c|c|}
\hline & & PH & SL & NL & $\mathbf{L L}$ & NS & LW & RT & YLD \\
\hline \multirow{4}{*}{$\begin{array}{l}\text { Cluster-1 (09) } \\
\text { [GCP-51,GCP-56,GCP- } \\
\text { 5,GCP-46,GCP-30,GCP- } \\
\text { 36,GCP-39,ACC-219, } \\
\text { KARTHIKA] }\end{array}$} & Mean & 64.54 & 48.22 & 15.86 & 22.32 & 7.26 & 2.29 & 2.13 & 4.50 \\
\hline & Min. & 59.82 & 45.61 & 14.83 & 20.08 & 5.67 & 2.11 & 1.98 & 3.13 \\
\hline & Max. & 70.63 & 53.72 & 16.67 & 23.79 & 8.33 & 2.61 & 2.32 & 6.41 \\
\hline & Variance & 9.25 & 6.86 & 0.47 & 2.00 & 0.93 & 0.03 & 0.01 & 0.76 \\
\hline \multirow{4}{*}{$\begin{array}{c}\text { Cluster-2 (09) } \\
\text { [GCP-14,SEHP-9,ACC- } \\
\text { 578,SE-86-31,SE- } \\
\text { 8640,SG-26-40,SE- } \\
\text { 8681,ACC- } \\
\text { 247,VARADA] }\end{array}$} & Mean & 54.63 & 36.71 & 12.76 & 19.98 & 4.94 & 2.13 & 2.35 & 6.23 \\
\hline & Min. & 50.72 & 33.18 & 10.67 & 17.64 & 3.33 & 1.99 & 1.88 & 3.59 \\
\hline & Max. & 61.31 & 43.00 & 15.00 & 22.29 & 6.17 & 2.26 & 2.95 & 8.89 \\
\hline & Variance & 14.01 & 9.11 & 1.62 & 2.91 & 0.86 & 0.01 & 0.09 & 3.45 \\
\hline \multirow[t]{4}{*}{ Entire Genotype (18) } & $\mathrm{Me}$ & 59.59 & 42.46 & 14.31 & 21.15 & 6.10 & 2.21 & 2.24 & 5.37 \\
\hline & Min. & 50.72 & 33.18 & 10.67 & 17.64 & 3.33 & 1.99 & 1.88 & 3.13 \\
\hline & $\mathrm{Ma}$ & 70.63 & 53.72 & 16.67 & 23.79 & 8.33 & 2.61 & 2.95 & 8.89 \\
\hline & Varian & 36.94 & 42.57 & 3.52 & 3.76 & 2.26 & 0.02 & 0.06 & 2.77 \\
\hline \multicolumn{2}{|l|}{ F Value } & 0.215 & 0.069 & 2.018 & 0.685 & 0.179 & 0.561 & 4.122 & 7.323 \\
\hline \multicolumn{2}{|l|}{$P$ value } & NS & NS & NS & NS & NS & NS & $* *$ & $* *$ \\
\hline
\end{tabular}

** variances were tested using Leven's test

$\mathrm{PH}=\mathrm{Plant}$ height $(\mathrm{cm}), \mathrm{SL}=$ Shoot length $(\mathrm{cm}), \mathrm{NL}=$ Number of leaves, $\mathrm{LL}=$ Leaf length $(\mathrm{cm}), \mathrm{NS}=$ Number of shoots, LW=Leaf width $(\mathrm{cm}), \mathrm{RT}=$ Rhizome thickness $(\mathrm{cm})$ YLD=Yield $(\mathrm{t} / \mathrm{ha})$

Fig.1 No of cluster (a) and cluster dendrogram (b) for different genotypes of ginger evaluated in Terai region of West Bengal

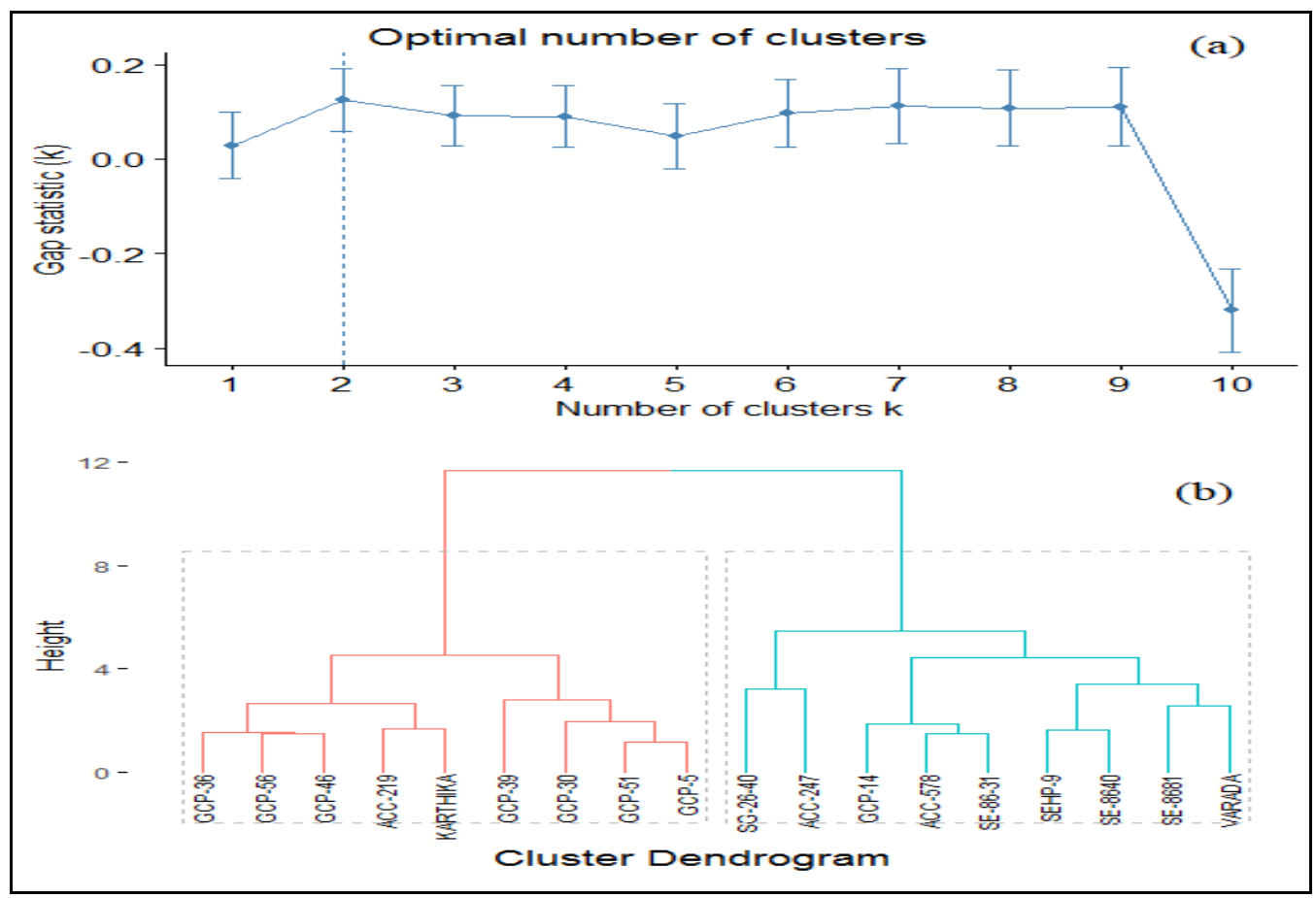


Fig.2 cluster biplot for different genotypes of ginger evaluated in Terai region of West Bengal

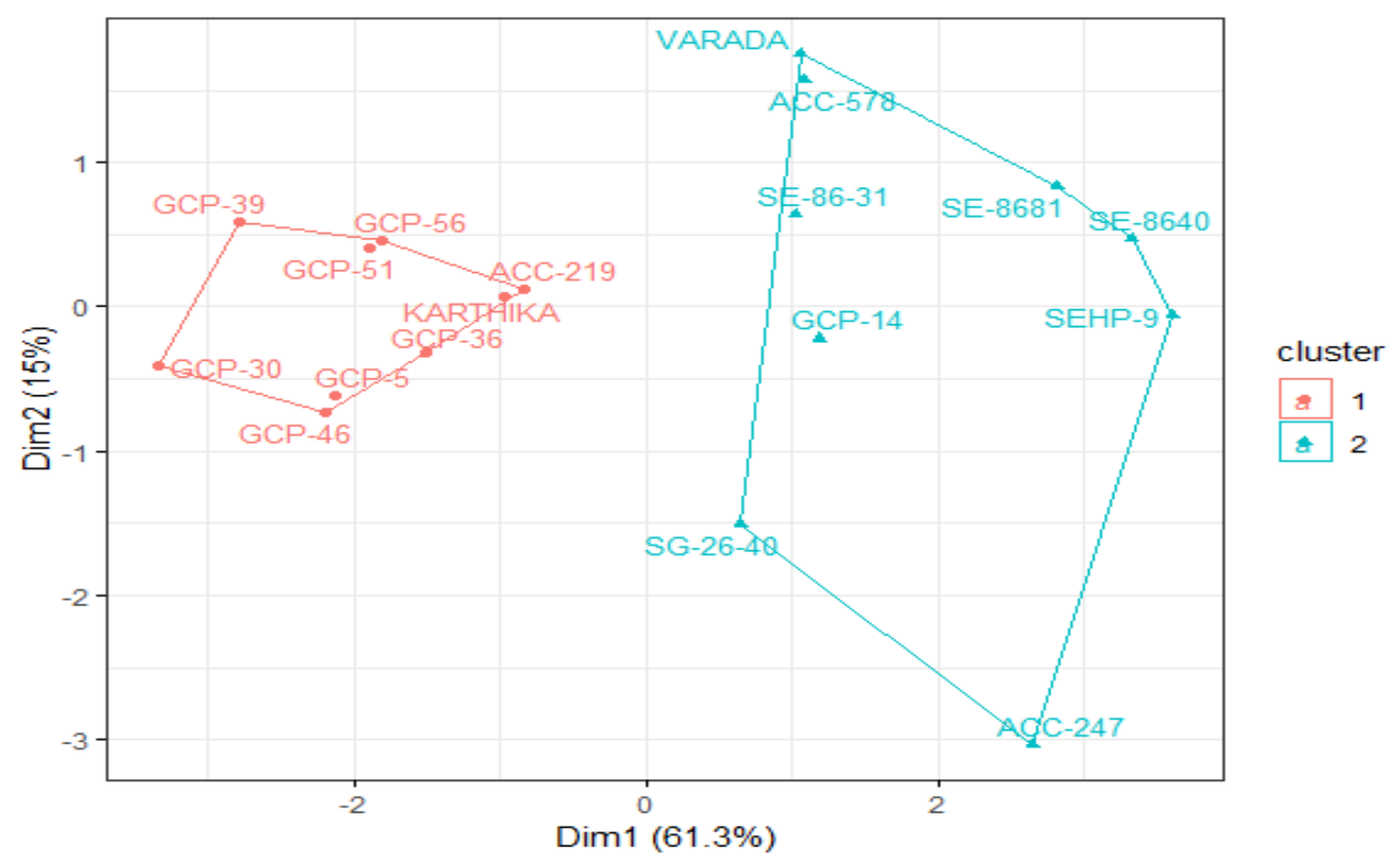

Cluster 1 consisted of 9 genotypes (GCP-51, GCP-56, GCP-5, GCP-46, GCP-30, GCP-36, GCP-39, ACC-219, KARTHIKA). Cluster 2 also consisted of 9 genotypes (GCP-14, SEHP-9, ACC-578, SE-86-31, SE-8640, SG26-40, SE-8681, ACC-247, VARADA). Cluster biplot (Fig. 2) also indicate the similar grouping of genotypes. Mean, Range and Variance for various traits of ginger under different clusters evaluated in Terai region of West Bengal are presented in Table 6.

The gap statistic (Tibshirani et.al. 2001) approach was applied for hierarchical clustering to identify the optimum number of clusters (Fig. 1a). The gap statistic compares the total intracluster variation for different values of $k$ with their expected values under null reference distribution of the data (i.e. a distribution with no obvious clustering).

The homogeneity of variances for different clusters was tested by Levene's test (Levene, 1960). The variances were heterogeneous
( $\mathrm{p}=0.05$ ) for Rhizome thickness and yield but variance were found homogeneous for other traits. Variance was more in cluster 2 for Rhizome thickness and yield.

In conclusion, the correlation coefficients among the different characters at phenotypic and genotypic levels revealed that Rhizome thickness $\left(0.45^{*}\right)$ was the only trait having positive and significant correlation with rhizome yield ( $\mathrm{t} / \mathrm{ha})$. Rhizome thickness is the only character we may choose for prediction of high yield. The data regarding genotypic path revealed that Number of leaves had the highest positive direct effect (1.759) on yield followed by number of shoots (1.053) and rhizome thickness (0.460). Clustering analysis and gap statistics was done to identify the optimum number of clusters and was found to have two groups according to closeness of maximum and minimum values and their respective variances among 18 genotypes. These characters could thus be utilized by breeders as selection criteria to develop 
higher yielding lines. From the present investigations it is concluded that for rhizome yield, genotypes SG-2640, SE-8681 and ACC-247 excelled the national check VARADA. Genotypes GCP-39, SEHP-9, SE8640, SG-2640, SE-8681 and ACC-247 excelled the local check GCP-5 for rhizome yield. These genotypes performed better for majority of the characters as well. Hence these genotypes can be recommended for cultivation in this particular region.

\section{References}

Abrahm, Z. and Latha, M. 2003. Correlation and path analysis in ginger (Zingiber officinale Rosc.). Journal of Spices and Aromatic Crops, 12 (2): 187-189.

Aragaw, M., Alamerew, S., Girma, M. H. and Tesfaye, A. 2011. Variability of ginger (Zingiber officinale Rosc.) accessions for morphological and some quality traits in Ethiopia. International Journal of Agricultural Research, 6 (6): 444-457.

Burton, G.W. and E.h. Devane, 1953. Estimating heritability in tall fescue (Festuca arundinacea) from replicated clonal material. Agron. J., 45:48-488.

Das, P., Rai, S. and Das, A. B. 1999. Genetic advance, heritability and path analysis in ginger (Zingiber officinale Rosc.). Journal of Plantation Crops, 27 (1): 27-30.

Islam, K.M., Islam, A. K., Rasul, M. G, Sultana, N. and Mian, M. A.K. 2008. Genetic variability and character association in ginger (Zingiber officinale Rosc.). Ann. Bangladesh Agric., 12(1): 33- 39.

Jatoi, A. S. and Watanbe, N. K. 2013. Diversity analysis and relationships among ginger landraces. Pakistan Journal of Botany, 45(4): 1203-1214.

Jatoi, S. A., Kikuchi, A., Mimura, M. Y. S. and Watanabe, N. 2008. Relationship of Zingiber species and genetic variability assessment in ginger $(Z$. officinale) accessions from ex-situ gene bank, on-farm and rural markets. Breed. Sci., 58: 261-270.

Levene H. 1960. Robust tests for equality of variances. In: Olkin I (ed.) Contributions to Probability and Statistics: Essays in honour of Harold Hotelling. Stanford University Press, Stanford, pp 278-292

Malhotra, S. and Singh, AP, 2003. Medicinal properties of ginger (Zingiber officinale Rosc.). Natiural Product reliance, 2(6): 296-301.

Mishra, R.K., Kumar, A. and Kumar, A. 2012. Pharmacological Activity of Zingiber officinale. International $J$. Pharm. Chem. Biol. Sci, 1 (3): 14221427.

Mohanty, D. C., Das, R.C. and Sarma, Y.N. 1981. Variability of agronomic characters in ginger (Zingiber officinale Rosc.). Orissa Journal of Horticulture, 9(1): 15-17.

Nandkangre, H., Ouedraogo, M. and Sawadogo, M. 2015. Caractérisation $\mathrm{du}$ système de production dugingembre (Zingiber officinale Rosc.) au Burkina Faso: Potentialités, contrainteset perspectives. Int. J. Biol. Chim. Sci, 9 (2): 861- 873.

Parmar, R. 2011. Molecular characterization of Zingiber officinale Rosc. germplasm in H.P. using RAPD as molecular markers. M.Sc. thesis. Dr.YSP UHF, Nauni, Solan, HP.

Peter, K. V. 2007. Spices. Horticultural Science Series-5, New India Publishing Agencies, New Delhi. 6768.

Rajyalakshmi, R. and Umajyothi, K. 2014. Evaluation of ginger (Zingiber officinale Rosc.) varieties in high altitude and tribal zone of Srikakulam district of Andhra Pradesh. Journal of 
Spices and Aromatic Crops, 23 (2): 258-261.

Rashid, K., Daran, A.B.M., Nezhadahmadi, A., Zainoldin, K.H.B., Azhar, S. and Efzueni, S. 2013. The effect of using gamma rays on morphological characteristics of ginger (Zingiber officinale Rosc.) plants. Life Sci. J.,10 (1): 1538-1544.

Ravi, Y., V.B. Narayanpur, J.S. Hiremath, S.S. Saraswati and Eragegowda, M. 2017. Correlation and Path Coefficient Analysis in Ginger (Zingiber officinale Rose.). Int. J. Curr. Microbiol. App. Sci, 6(4): 1224-1230.

Ravindran, P.N., Nirmal Babu, K., Peter, K.V., Abraham, Z. and Tyagi, R.K. 2005 Spices. In: B.S. Dhillon, R.K. Tyagi, S. Saxena and G.J. Randhawa (eds) Plant Genetic Resources: Horticultural Crops, Narosa Publishing House, New Delhi. 190 227.

Sasikumar, B., Nirmal Babu, K. Abraham, J. and Ravindran, P. N. 1992.
Variability, correlation and path analysis in ginger germplasm. The Indian Journal of Genetics and Plant Breeding, 52(4): 428-431.

Singh, Y., Katoch, V. and Mittal, P. 2002. Variability studies in ginger (Zingiber officinale Rosc.) under humid subtemperate conditions of Himachal Pradesh. Proceedings of the 15th plantation crops symposium (placrosym xv), Mysore. India. 173175.

Tibshirani, R., G. Walther, and T. Hastie. 2001. Estimating the number of clusters in a data set via gap statistic. J. R. Statist. Soc. B. 63 (2):411-423

Vasala, P.A. 2001. Ginger. In K.V. PETER. eds. Handbook of herbs and spices. CRC Press. Abington, Cambridge, England. 195-205.

Yadav, R. K. 1999. Genetic variability in ginger (Zingiber officinale Rosc.). Journal of Spices and Aromatic Crops, 8(1): 81-83.

\section{How to cite this article:}

Basak, D., S. Chakraborty, A. Sarkar, M.K. Debnath, A. Kundu and Khalko, S. 2019. Characterization and Genetic Potential of Ginger Genotypes Evaluated in Terai Region of West Bengal, India. Int.J.Curr.Microbiol.App.Sci. 8(04): 1147-1157. doi: https://doi.org/10.20546/ijcmas.2019.804.132 